\title{
May '68 and the One-Dimensional State
}

\author{
Chris Reynolds
}

Herbert Marcuse's One-Dimensional Man is often perceived as encapsulating the underlying frustrations that drove the events of 1968 around the world, with the German philosopher described by some as the "guru" of the New Left (Klimke and Scharloth 100-01). The influence of this text is perceived as particularly strong in France where the events of May '68 seemed to reflect the frustrations delineated by Marcuse (Olivers 71; Capdeveille and Rey 286-8). Kristin Ross comments that Marcuse's ideas continue "à être évoquée de manière persistante comme [celles] qui [ont] dirigé à distance les événements parisiens" (Ross 203). As the years have passed, a certain conventional representation of the French events has emerged; one that is limited to a Paris-based, student protest movement that—headed up by highly militant extreme left-wing students—-set out to challenge the system in a nihilistic and utopian manner. Just as les événements have been reduced as a result of this ever-narrowing representation, so too has the pertinence of the ideas professed in One-Dimensional Man. Marcuse's ideasappropriated by the gauchiste elements and incorporated as such into the dominant discourseare predominantly viewed as fitting the motivations of those that have come to dominate the stereotypical portrayal of the events. In a bid to deconstruct the stereotypical image, an emerging trend in more recent studies on the 1968 events in France has seen a focus on the oft-forgotten provincial revolts of this time (Reynolds 209-22; Barral and Jeanjean; Lougart; Robin). 
By highlighting the pertinence of Marcuse's 1964 text in relation to the revolts of Brest and Strasbourg, this article seeks to further problematize the dominant discourse. Focussing on these cities as representative of two regions that were on the periphery (geographically, historically and in terms of identity), I will argue that the relevance of Marcuse's ideas concerning the source of revolt emanating from those who found themselves on the margins of society can be extended beyond the gauchiste optic to a less obvious sector, explaining further why this seminal text is so important in any understanding of 1968.

\section{The One-Dimensional Man and May '68}

Born in Germany in 1898, Herbert Marcuse was forced to flee to the USA in 1933. After a number of years as an employee of the Office of Secret Services, he left in the early 1950s and turned his attention to his academic interests, publishing Eros and Civilisation in 1955 (Kurlansky 108-09). By 1958, he had a position at Brandeis University where he established a reputation as one of the most prominent Marxist philosophers of his time. Two developments combined to thrust Marcuse into the limelight in the mid-to-late 1960s. Firstly, the death of C. Wright Mills- the inspirational American sociologist and "transnational lodestar" —in 1962 left a gaping hole crying out for a new radical thinker capable of catching the mood of the time. Marcuse proved his credentials to fill the void with the second development: the 1964 publication of One Dimensional Man (Horn 146-48).

The period 1964-68 saw him consolidate his reputation as he travelled the world bringing his ideas to meetings and conferences. The One Dimensional Man thesis appeared to find mounting support amongst an increasingly frustrated international generation of youths (Klimke and Scharloth 106). Marcuse outlines how the advanced capitalist system, assisted by 
technological advances, had managed to suppress any opposition to the status quo (the onedimensional state). He laments the emergence of a totalitarian-like system that had been able to steer all aspects of life in one irrevocable direction while rendering impossible alternatives or opposition. Such was the strength of this system, he argues, that the only potential source for opposition resided on the margins of society. Those people who found themselves alienated or excluded from the system would be the origin of what Marcuse describes as the "Great Refusal" (Marcuse 257).

Across the world, 1968 seemed to mark the coming together of a whole raft of socioeconomic and political factors that brought latent frustrations to the surface. Marcuse's lamentations resonated with many of those that found or rediscovered their voice during this period. As the signs of frustration became increasingly evident and their international aspect more apparent, Marcuse's popularity soared. In fact, his ideas have increasingly been depicted as perhaps one source of the glue that was holding this diverse outburst of frustration together, or as "le fédérateur des révoltes qui se développent aux quatre coins du monde" (Trebitsch 71). Nevertheless, despite his undoubted international appeal and growing reputation in the years building up to 1968, his notoriety in France was not widespread: “On a désigné Marcuse comme 'maître à penser' du mouvement alors qu'il avait été très peu lu, dans les faits, avant cette époque, et même ignoré de bien des militants" (Combes 89). In fact, before the events exploded in France Marcuse was, if not a virtual unknown, an underground figure (Trebitsch 71-5; Zancarini-Fournel 191-4). His notoriety would in fact come following the crisis (Le Goff 283). When the dust had settled on the French events, there was a great desire amongst commentators, activists, supporters, politicians and opponents to make sense of what had occurred (Seidman 80). In many respects, the outpouring of texts in the immediate aftermath reflects not only a 
continuation of the verbosity that so characterized the events but also the overwhelming desire amongst the population to take stock and understand. It was in this atmosphere that Marcuse, and in particular his One-Dimensional Man, became popular. One can therefore not talk of a direct influence of Marcuse on the events themselves but instead of a retrospective application of his theories, or, as some have argued, "C'est ... Mai 68 qui invente Marcuse" (Trebitsch 72). Not only did these ideas help explain how the French events fitted in with a more international malaise, they also provided gauchistes with a theoretical underpinning that would ensure a certain level of credibility for their movement. From this point on, the amalgam was in place and any discussion of Marcuse and 1968 in France was inextricably linked to gauchisme. The theories of One-Dimensional Man to all intents and purposes had been appropriated and monopolized by what in reality was only ever a very small minority of the 1968 protest (Fischer 396). In this paper I will argue that, just as extreme left-wing elements were able to map Marcusian theory onto "their '68," so too can the ideas of One-Dimensional Man be used to explain the participation of, and impact on, other sectors of French society, and in particular, regional movements.

\section{Historical Context}

A brief consideration of the respective histories of Brittany and Alsace is required in order to situate the circumstances of the pre-' 68 period in Strasbourg and Brest. Independent from France until 1532, Brittany had always existed very much on the margins. Over the next four centuries the regional specificities that set it apart were the focus of a sustained campaign of eradication as efforts were made to render this region as French as possible. ${ }^{1}$ From serious economic difficulties and a youth exodus (Favereau 55), the first emsav emerged before being 
halted in its progress by the onset of the First World War (Favereau 172) when almost one quarter of a million Bretons lost their lives (Markale 175). ${ }^{2}$ Resentment of these losses fuelled the creation of a second, more violent emsav (Skol Vreizh 118-33) whose extremist elements would tarnish the reputation of all things Breton through their open collaboration with the Nazis during the Second World War. ${ }^{3}$ The history of Alsace is equally eventful. Until 1648 the region had been under the control of Celts, Romans, Francs and Germans, as well as forming part of the Holy Roman Empire. Between the Treaty of Westphalia and 1945, the region changed nationality five times, as it became the focus of a bitter power struggle between France and Germany. ${ }^{4}$ The flux that characterized the past led to the emergence of a hybrid culture grounded mainly in French and German identity. Such difficulties inevitably led to some elements believing that the only hope for the region lay in autonomy. Just as had been the case in Brittany, the actions of extremist elements would further undermine the standing of the Alsatian identity through their decision to collaborate with the Nazi occupiers. ${ }^{5}$ Despite their divergent trajectories, in both cases, historical specificities led to errors during the occupation that would have significant ramifications for the place of the respective regional identities. Between 1945 and 1968 any affirmation of cultural difference was sidelined in both Brittany and Alsace as efforts were made to overcome the collaborationist errors of a minority, and were used to stifle any renaissance in regionalism so as to consolidate the Jacobinism of the $4^{\text {th }}$ Republic and the first 10 years of the $5^{\text {th }} 6$

\section{Pre-'68 Provincial France}

Brest provides a particularly accurate representation of the difficulties being experienced across Brittany in the years leading up to 1968. The benefits of a hasty post-war reconstruction 
programme soon subsided (Skol Vreizh 184) giving way to mass unemployment, lack of funding and a continuing youth exodus. ${ }^{7}$ By the late 60 s, there was a real feeling of isolation amongst the population (Monange 12). Tertiary education and the opportunities it afforded were viewed as somewhat of a privilege by young Bretons, the majority of whom were from agricultural backgrounds (Reynolds 212-13). The possibility of escaping the dire economic predicament of the time meant that Brestois students were wholeheartedly committed to their studies, leading to little in the way of militant student activity. ${ }^{8}$ The Collège littéraire universitaire, as well as struggling to meet the demands of the baby-boom, was confronted by a series of localized difficulties-including incomplete courses and the frequent absence of teaching staffassociated with its over-dependence on the University of Rennes (Monange 16). The coming together of local and national tensions created a fertile ground for revolt but one that, due to a specific set of circumstances, sits outside how the events of 1968 are commonly portrayed (Porhel, Mai 68 au CLU de Brest 25). In contrast to Brest, Strasbourg during the same period was enjoying the benefits of the political and economic stability of the $5^{\text {th }}$ Republic (Wendling 14). For the inherently conservative population (Ritter 69), the Gaullist regime was a welcome break from the chaos of the past, a fact reflected in the complete dominance of Gaullism on the political landscape (Volger, Histoire politique 292-98; Wendling 14-17; Straus and Richez 119). Any pressures on the University system were similar to those being felt nationally. ${ }^{9}$ The scandal of 1966 that saw the Strasbourg branch of the Internationale situationniste (IS) take control of the Association fédérale des étudiants de Strasbourg (AFGES) does suggest some signs of what was to come. ${ }^{10}$ However, despite creating a stir amongst university authorities and ensuring a national reputation for Strasbourg as a hotbed of student militancy, locally by 1968 the influence of this movement had dissipated and the general student majority could be described as 
conforming to the national trend of relative political apathy (Fischer 382). Nevertheless, local specificities in Strasbourg had created a particular set of circumstances that led to events that question the validity of the dominant narrative of May '68.

\section{Strasbourg/Brest '68}

Both cities were drawn into the revolt by events in the capital and in each case the university served as the starting point. ${ }^{11}$ However, contrary to the iconic images of intense battles between protestors and the forces of order, in Brest the CRS (Compagnie républicaine de sécurité) was nowhere to be seen (Reynolds 217). All marches were conducted calmly and always following consultation with the police - a factor that at one stage enabled opposing sides to demonstrate at the same time around the narrow streets of Brest (Monange 20). Such a measured approach was replicated in Strasbourg where there was a virtual absence of violence. The conservative population remained tolerant of the revolt until it showed signs of replicating the chienlit of the Latin Quarter (Feurestein 43; Livet 199-200). In both cities this reasonable approach underpinned the nature of the university movements. The stereotypical idea of students intent on destroying a system with no consideration of what could replace it is inapplicable to an analysis of these provincial revolts. The principal motivation of the majority of those involved was the reform of the system of higher education. ${ }^{12}$ The seriousness and commitment of this reformist element is evidenced through the plethora of communiqués and proposals ${ }^{13}$ produced as well as the prominent place of both Brest and Strasbourg on the front-line of this frequently forgotten aspect of the 1968 events (Reynolds 219; Feurestein 57). In other aspects, convergence was not so obvious. However, such differences only serve to further underscore the sheer diversity of how the ' 68 events played out on a national scale. 
While the economic stability of Alsace feeds into the argument that the events were a surprise, the Breton predicament provided clear evidence of mounting tension. The mass support of 8 May l'Ouest veut vivre demonstrations and strikes in protest against the prevalent economic instability (Reynolds 214) problematizes the assumption that the events exploded during a period of extensive economic and political stability (Sainclivier 430). A further point concerns the magnitude of the revolt. In Brest the revolt was widespread and saw participation and fruitful contacts across sectors with a sustained general strike paralysing the city until late June (Monange 17; Reynolds 216-17). On the other hand, in Strasbourg, while the strike did take hold, it did not last as long, workers and students were kept apart and there was never any feeling of paralysis (Strauss and Richez 129; De Chalendar 25). Despite these differences that highlight the inadequacies and narrowness of the conventional representation, there was a common consequence related to the issue of the regional identities.

\section{Regional Renaissance}

From both a Breton and an Alsatian point of view, 1968 marked the beginning of what can be described as a regional renaissance. This came about for a number of reasons. Firstlyand and one can cite the hugely important "Plan Breton" as an example (Le Bourdennec 231) — there was a clear shift in how the state would address regional issues. A process began that hasthrough the instauration of regional assemblies, regional councils, cultural charters, etc.gradually decentralised powers from Paris to the provinces with the most recent reform being the 2004 constitutional change (Le Galès 201-03). It could be argued that an upturn in regional fortunes had started well before the events and therefore any link with 1968 is no more than coincidental. However, a brief examination of the post-' 68 period in Alsace and Brittany will 
reveal how the adjustment in government policy coincided with (and was arguably influenced by) a cultural reinvigoration borne by the ' 68 events.

Most symbolic of this revitalisation was the resurgence in activism linked to the question of regional dialects. In both regions the post-' 68 period saw a surge in the number of organizations putting the issues of bilingualism very much back on the agenda (Sainclivier 475; Aubert and Sonocinski 14), a situation that Fanch Broudig considers "inimaginable avant Mai 68" (Broudig, interview). ${ }^{14}$ These movements were bolstered by singers such as Roger Siffer in Alsace (Vogler, Histoire culturelle 493-500), who considers regional movements as "des enfants directs de Mai '68" (Siffer, interview), and Alan Stivell (Chédeville and Croix 125) in Brittany, whose popularity and success did much to help encourage this reinvigorated élan. ${ }^{15}$ The next stage in this development saw a boom in the literary output that served to confirm and consolidate the growing prevalence of the new-found interest in regional cultures. ${ }^{16}$ Eventually, such progress led to increasing space and air time being afforded to regional dialects in the media (Nicolas 137; Richez 5298). Generally, regional specificities were increasingly pushed to the fore and the reticence in the affirmation of one's regional identity that had so marked the 194568 period in both Alsace and Brittany had been lifted. As Vogler describes in the case of Alsace, “[1]'effervescence suscitée par l'agitation de mai conduit à une décrispation, un déblocage après le sentiment de culpabilité qui a étouffé l'Alsace depuis 1945" (Vogler, Histoire culturelle 465).

Finally, from a French but also an international perspective, the coming of age of the baby-boom generation-numerically significant, less insular and with a radically different set of priorities to that of their parents and grandparents - is a fundamentally important element in making sense of how and why the '68 events came about. This factor is an equally key consideration in the post-' 68 regional renaissance. Young Bretons and Alsatians, unlike previous 
generations, were free from the burden of past mistakes and were able to affirm, consolidate and ultimately celebrate their respective regional identities "sans soupçon de pan-germanisme" (Siffer, interview); '68 “a permis de tourner la page” (Jean le Roux, interview), helping to disassociate regionalism from the collaborationist tendencies of the Occupation. ${ }^{17}$ This reinvigorated, youth-driven movement refused to carry the shame so often attached to the affirmation of their regional culture and—in what Stefan Collini has described as the "decline of deference" (Collini 270)—demanded a new beginning. As Bernard Boudic declared, "il est devenu possible à dire, 'nous aussi on peut, nous aussi' — cette idée de 'nous aussi on peut' était plus vivace" (Boudic, interview). ${ }^{18}$

\section{The One-Dimensional State}

In One-Dimensional Man, Marcuse outlines the emergence of a system that managed to suppress any opposition to the status quo or the one-dimensional state. De Gaulle's highly centralised $5^{\text {th }}$ Republic could be interpreted as representing the overbearing system that Marcuse claims was preventing the expression of alternatives or opposition. Such theories struck chords with anti-capitalists, civil-rights activists and counter-culture movements that had come to the fore during les années 68 (Dreyfus-Armand). Therein lies an explanation for the success of Marcuse's One-Dimensional Man. It was and remains possible to interpret such groups as representing those on the margins of society that the philosopher claims would be the source of the "Great Refusal." The fact that such groups were prominent during the '68 events and/or experienced a certain reinvigoration as a result adds weight to the Marcusian thesis whereby those on the margins of the monolithic system would be the most potent source of opposition to it. The post-war marginalization of regionalism in order to fit the over-arching national discourse 
of unity fits such a paradigm. Marcuse describes how the one-dimensional state marginalizes "outcasts and outsiders" that do not fit the dominant system (Marcuse 256-57) and how "under the conditions of a rising standard of living, non-conformity with the system itself appears to be socially useless ... and threatens the smooth operation of the whole" (Marcuse 2). The post-war backlash would certainly allow regional movements to consider themselves at the time as part of this "substratum." In a system where "culture, politics, and the economy merge into an omnipresent system which swallows or repulses all alternatives" (Marcuse xvi) regional movements could well have considered the affirmation of their specific identity as a threat to the "National Purpose," the obvious consequence of which is a "decline of pluralism" as discussed by Marcuse as an upshot of the one-dimensional state. He details how the system maintains its stranglehold through the "containment of social change" (Marcuse xii). These ideas can be extended to capture the sentiments of regionalists who felt excluded and powerless, faced with their very difficult predicament in late 1960s France.

The desire of the French state to consolidate unity across the entire national territory had been a long-term objective and one that was facilitated in the post-war period. As discussed above, the collaborationist errors of regionalists in both Brittany and Alsace led to a window of opportunity for those intent on quashing regional differences. The combination of the expressed need for national unity following the horrors of the Second World War and the amalgam between regionalism and collaborationist tendencies brought about a situation whereby any overt regionalism was virtually impossible. There were (often clandestine) efforts to maintain cultural activities. ${ }^{19}$ However, the prevailing attitude was one of reticence in the affirmation of regional difference. Such an atmosphere can be equated with the forms of control described by Marcuse where "independence of thought, autonomy, and the right to political opposition are being 
deprived their basic critical function" (Marcuse 1). Such control is described as leading to a "pattern of one-dimensional thought and behaviour in which ideas, aspirations, and objectives that by their content transcend the established universe of discourse and action are either repelled or reduced to terms of this universe" (Marcuse 12). The powerlessness felt by regional movements faced with such challenges was exacerbated by the sense that the highly centralized system ignored regional voices. Such a lack of input in the decision making processes further underscored the feeling of marginalization. This was particularly the case in Brittany, where the period was marked by growing frustration at the perceived economic enclavement of the region (Poussier 53; Favereau175; Philipponneau). Such sentiments are described by Marcuse as symptoms experienced by victims of the one-dimensional state: "Decisions are made at places over which individuals have no control" (Marcuse 32).

Regionalists logically sit alongside the various groups that could be considered as isolated from mainstream French society and therefore part of this "substratum of outcasts and outsiders" (Marcuse 256). Marcuse believed that those on the margins were the most potent source of revolt and threat for the one-dimensional state. He declares that "the fact that they start refusing to play the game may be the fact which marks the beginning of the end of a period" (Marcuse 257) and as this article has shown, for the regionalist cause this is very much the case. When Marcuse refers to Maurice Blanchot, who declared that "une rupture s'est produite" (Marcuse 256), the relevance of his ideas for those intent on a new dawn from a regional perspective is obvious. From this clean slate, and helped by the process of progressive decentralisation (and, in the Breton case, by the region's economic development), the regional diversity of France has gone from being perceived as an inherent weakness to be eradicated to 
becoming one of the nation's most feted strengths in what Le Galès describes as the "Silent Revolution" (Le Galès 201).

\section{Conclusion}

The events of 1968 have been interpreted as an outcry by those on the margins or made to feel on the margins of a society dominated by a one-dimensional discourse. Such a perspective provides some clues to help explain the popularity of Marcuse's One-Dimensional Man. For many people, it encapsulated the desires of many of those who were shaken into action in 1968 and/or experienced it as a crucial turning point in various activist developments. Such commonly cited movements include those led by gay-rights activists, feminists and ecologists. To this list should be added regional movements. Indeed, the events of 1968 were hugely significant in the emergence of a reinvigorated regionalism that spawned a new generation of activists and a period of fundamental change. The case for their inclusion is strengthened by the fact that the ideas of one of the seminal theoretical texts of the period are relevant to the predicament of regionalists at this time. Just as conventional representations of May '68 are dominated by a gauchiste perspective, the pertinence of One Dimensional Man is all too often victim of such a telescopic analysis. This article argues that if gauchistes were able to retrospectively apply Marcusian theory to provide a theoretical underpinning to their movement, then so too should regionalists.

However, the pertinence of the Marcusian theory in this debate arguably does not end there. How should we interpret the shifting stance of the state post-1968 regarding the question of regionalism? Should we read this change as recognition of the fact that regional identities could no longer be denied and the issue ignored? Or could the recuperative measures employed 
by the state be interpreted as the desublimation (Marcuse 56-83) of regionalism serving to further emphasize the relevance of the ideas of One Dimensional Man, where regionalism is "part and parcel of the society in which it happens, but nowhere its negation" (Marcuse 77)?

\section{Notes}

${ }^{1}$ For a detailed analysis of the period 1532-1789, see Poisson and Le Matt (252-370) and Markale (86).

${ }^{2}$ Emsav is the term used to describe collection of organizations whose aim is the recognition of the specific nature of Breton culture and identity.

For a more detailed analysis of the development of the Breton economic situation at this time, see Guin (95-134).

${ }^{3}$ For a detailed analysis of those involved in preparing the ground for the collaboration between Breton militants and the imminent Nazi occupiers, see Guin (220).

4 For a more detailed overview of this early history see Meyer; Bernard Vogler, Histoire culturelle de l'Alsace; Vogler, Histoire politique de l'Alsace.

${ }^{5}$ For discussion of issue of collaborators, see Ritter (62) and Volger, Histoire politique (264-66).

${ }^{6}$ For Alsace see Vogler, Histoire culturelle (461-462). For Brittany, see Chédeville and Croix (117).

${ }^{7}$ For a more in-depth analysis of the demographic situation of the region see Quintin.

${ }^{8}$ For a detailed analysis of the 68 events in the CLU, see Porhel, Mai 68 au CLU de Brest.

${ }^{9}$ For analysis of the problems experienced within the university system nationally, see Christine Musselin; Fischer; Prost. For a more local analysis, see Ackner (6369); Feuerstein (16-17).

${ }^{10}$ Some useful material on this episode includes Feuerstein (20); Livet (159); "De Strasbourg, lettrisme et situationnisme hier et aujourd'hui" (61-63); "10 jours qui ébranlèrent Strasbourg ou l'Internationale situationniste se donne en spectacle." 1968; Amann.

11 For a detailed account of events in Strasbourg see Olivier-Utard (2-5); de Chalendar (411);Wendling; Straus and Richez (121-28); Haas; Ackner (6369-6374); Feuerstein (24-57); "Le mai de Strasbourg. Chronologie des mouvements étudiants qui se manifestent à Strasbourg en 
particulier durant le mois de mai et juin" 1968 (118-24). For Brest, see Reynolds; Monange; Porhel, L'Autogestion à la CSF (379-97); Porhel, Mai 68 au CLU de Brest; Jeffroy; Le Roux.

${ }^{12}$ For Brest, see Le Roux 36. For Strasbourg, see Feurestein (38-40).

13 The collection of Les Archives de la Ville is dominated by the work of the various commission paritaires and underline the importance of the reformist sector in the Strasbourg university movement.

${ }^{14}$ Fanch Broudig is a highly respected and famous member of the Breton language movement, most notably known for his regular news programmes in Breton on France 2.

${ }^{15}$ Roger Siffer is a well-known figure in the Alsace cultural movement.

${ }^{16}$ For Brittany, see Le Bourdennec (36). For Alsace, see Richez (5293).

${ }^{17}$ Jean Le Roux was a prominent member of the Brestois student movement in 1968.

${ }^{18}$ Bernard Boudic, President of the Association générale des étudiants brestois (AGEB) in 1968, a highly prominent member of the Brestois branch of the UNEF and a major protagonist in these regional events.

${ }^{19}$ For Alsace, see Jean-Claude Richez (5292). For Brittany, see Dugalès, le Coadic and Patez (165).

\section{Works Cited}

Ackner, Agnes, “Révolte de Mai 1968.” Encyclopédie de l’Alsace. Strasbourg: Publitotal, 1982. 6369.

Amann, Remy. Le scandale de Strasbourg ou l'épisode situationniste de la capitale alsacienne, Mémoire de maîtrise, Université de Strasbourg, 1990.

Aubert, Gireg and Sonocinski, Aurélie. “1945-2004: le regain du régionalisme.” News d'ill, no. 75 (February 2004): 14.

Barral, Antoine and Jeanjean, Anne-Marie. Mai 68: échos du Languedoc. Perpignan: Cap Bear éditions, 2008.

Boudic, Bernard, interview with author, 24 January 2005. 
Broudig, Franch, interview with author, 3 August, 2004.

Capdeveille, Jacques and Rey, Henri. Le dictionnaire de Mai 68. Paris: Larousse, 2008.

Chédeville, André and Croix, Alain. Histoire de la Bretagne. Paris: P.U.F., 1993.

Collini, Stefan. Common Reading. Critics, Historians, Publics. Oxford: Oxford University Press, 2008.

Combes, Patrick. La littérature et le mouvement de Mai 68. Paris : Seghers, 1984.

De Chalendar, Hervé. “Mai 68, un printemps en Alsace.” L'Alsace, Hors série, (February 2008): 4-11.

"De Strasbourg, lettrisme et situationnisme hier et aujourd'hui." Cahiers/Chroniques, No. 3, Université de Strasbourg: 61-63.

Dugalès, Nathalie, Le Coadic, Roanan and Patez, Fabrice. Et la Bretagne? Rennes: Presses Universitaires de Rennes, 2004.

Favereau, Francis. Bretagne contemporaine. Langue, culture, identité. Morlaix: Embannadurioù Skol Vreizh, 1993.

Feuerstein, Pierre. Printemps de révolté à Strasbourg, mai-juin 1968. Strasbourg: Saisons d'Alsace, 1968.

Fischer, Didier. L'histoire des étudiants de 1945 à nos jours. Saint-Amand-Montrond: Flammarion, 2000.

Guin, Yannick. Histoire de la Bretagne de 1989 à nos jours. Contribution à la critique de l'idéologie nationaliste. Paris: Maspero, 1982.

Haas, Jean-Paul. La révolution inutile. Strasbourg, Oberlin, 1987.

Horn, Gerd-Rainer. The Spirit of '68. Rebellion in Western Europe and North America, 19561976. Oxford: OUP, 2007.

Jeffroy, Annie. Chronique des événements de Mai 1968 à Brest d'après le 'Télégramme' et ‘Ouest-France,’ Mémoire de maîtrise, UBO, 1987.

Klimke, Martin and Scharloth, Joachim. 1968 in Europe. A History of Protest and Activism, 1956-1977. Hampshire: Palgrave, 2008.

Kurlansky, Mark. 1968 The Year the Rocked the World. London: Vintage, 2004.

Le Bourdennec, Yannick. Le miracle Breton. Paris: Calmann-Levy, 1996. 
Le Galès, Patrick. "The Ongoing March of Decentralisation within the Post-Jacobin State." Changing France. Ed. Pepper D. Culpepper. Basingstoke: Palgrave, 2006.

Le Goff, Jean-Pierre. Mai 68, l’héritage impossible. Paris: La Découverte, 1998.

"Le mai de Strasbourg. Chronologie des mouvements étudiants qui se manifestent à Strasbourg en particulier durant les mois de mai et juin 1968." Bulletin d'information université de Strasbourg, no. 15 (1968): 118-24.

Le Roux, Jean, interview with author, 22 January 2005.

—. "Mai 1968 et les étudiants de Brest." En avant, no. 317 (1968): 36.

Livet, Georges. 50 années à l'Université de Strasbourg. Strasbourg: Société savante d'Alsace, 1998.

Lougart, Gisèle. Pays Basque Nord, Mai 68 en mémoires. Bayonne: Elkar, 2008.

Marcuse, Herbert. One-Dimensional Man. Boston: Beacon Press, 1964.

Markale, Jean. Identité de Bretagne. Mayenne: Entente, 1985.

Meyer, Philippe. Histoire de l'Alsace. Paris: Perrin, 2008.

Monange, Edmond. “Mai 68 à Brest.”, Les Cahiers de l'Iroise, no. 176 (1998).

Musselin, Christine. La longue marche des universités françaises. Paris: P.U.F., 2001.

Nicolas, Michel. Bretagne, un destin européen. Rennes: Presses universitaires de Rennes, 2001.

Olivier-Utard, Françoise. “Les ‘événements’ de Mai 68 en Alsace.” Almémos, no. 12 (2008): 2-5.

Olivers, Philippe. "Les livres de Mai.” Mai-Juin 68. Damamme, Dominique. Paris: Éditions de l'Atelier/Éditions ouvrières, 2008.

Philipponneau, Michel. Les ouvriers bretons. St-Brieuc: Presses universitaires de Bretagne, 1972.

Poisson, Henri and Le Matt, Jean-Pierre. Histoire de la Bretagne. Nantes: COOP Breizh, 2000.

Porhel, Vincent. Mai 68 au CLU de Brest. Mémoire de maîtrise, UBO, 1988 (supervised by Edmond Monange).

-. "L'Autogestion à la CSF de Brest." Les années 68. Dreyfus-Armand, Frank, Lévy, Zancarini-Fournel, 379-97.

Poussier, Jean-Luc. Bretagne. Paris: Lec, 1997. 
Prost, Antoine. “1968: mort et naissance de l'université française.” Vingtième siècle, No. 23 (1989).

Quintin, Philippe. De l'exode rural à la rurbanisation: les mouvements de population active dans l'Ouest entre 1962 et 1990. INSEE, octant no. 75.

Reynolds, Chris. "Understanding 1968: The Case of Brest." Modern and Contemporary France, Vol. 16, No. 2 (2008): 209-222.

Richez, Jean-Claude. "Mouvements culturels en Alsace.” Encyclopédie de l'Alsace, vol. ix (1984): 5292.

Ritter, Jean. L’Alsace. Paris: P.U.F., 1985.

Robin, Pierre. Mai 68 en Lot-et-Garonne. Nérac: Albret, 2008.

Ross, Kristin. Mai 68 et ses vies ultérieures. Paris: Complexe, 2005.

Sainclivier, Jacqueline. La Bretagne de 1939 à nos jours. Éditions Ouest France, 1989.

Seidman, Michael. The Imaginary Revolution. Parisian Students and Workers in 1968. New York: Berghan Books, 2004.

Siffer, Roger, interview with author, 26 June 2008.

Skol Vreizh, La Bretagne au XX siècle. Histoire de la Bretagne et des pays celtiques de 1914 à nos jours. Morlaix: Skol Vreizh 1983.

Strauss, Léon and Richez, Jean-Claude "Le mouvement social de mai 1968 en Alsace: décalages et développements inégaux." Revue des sciences sociales de la France de l'Est, no. 17 (1989-90).

Trebitsch, Michel. "Les circulations de la pensée critique de 1956 à 1968." Dreyfus-Armand, G. Les années 68. Le temps de la contestation. Paris: Complexe 2000.

Vogler, Bernard. Histoire culturelle de l'Alsace. Du Moyen Âge à nos jours, les très riches heures d'une région frontière. Strasbourg: La Nuée Bleue, 1993.

-. Histoire politique de l'Alsace. De la Révolution à nos jours, un panorama des passions alsaciennes. Strasbourg: La Nuée Bleue, 1995.

Wendling, Yvonne. Les feuilles de Mai 68 à Strasbourg, Mémoire de maîtrise. Strasbourg, 1992.

Zancarini-Fournel, Michelle. Le moment 68. Une histoire contestée. Paris : Seuil, 2008.

"10 jours qui ébranlèrent Strasbourg ou l'internationale situationniste se donne en spectacle." Gros sel, no. 8 (1968). 